\title{
Cutaneous blastomycosis: a clue to a systemic disease*
}

\author{
Blastomicose cutânea: um sinal de doença sistêmica
}

\author{
Alex G Ortega-Loayza ${ }^{1}$
}

\author{
Tuyet Nguyen ${ }^{1}$
}

\begin{abstract}
A 55-year-old male presented with back pain and slightly tender annular plaques with central ulceration on his face. A skin biopsy revealed scattered yeast with broad based buds. A CT scan of the abdomen revealed a pathologic T12 fracture. Tissue obtained from the spine confirmed budding yeasts. The patient was diagnosed with disseminated blastomycosis. The patient was treated with amphotericin and itraconazole and completely recovered.
\end{abstract}

Keywords: Blastomycosis; Chromoblastomycosis; Coccidioidomycosis; Paracoccidioidomycosis

Resumo: Paciente do sexo masculino, com 55 anos de idade, compareceu ao ambulatório com dores na costa e placas anulares ligeiramente sensíveis, com ulceração central na face. Uma biópsia cutânea revelou levedura disseminada, com brotos de base larga. A tomografia computadorizada do abdômen revelou uma fratura patológica da T12. Amostra de tecido obtido da coluna vertebral confirmou levedura em fase de brotamento. O paciente foi diagnosticado com blastomicose disseminada. Após tratamento com anfotericina e itraconazol, o paciente teve recuperação completa.

Palavras-chave: Blastomicose; Cromoblastomicose; Coccidioidomicose; Paracoccidioidomicose

A 55 year-old white male from Virginia, USA presented to the emergency room with right flank and back pain for approximately three weeks and a facial eruption without other symptoms. On physical examination, the patient was found to have verrucous plaques with raised borders and eroded centers on the left paranasal labial fold and right jawline (Figures 1 and 2). There was no pain to palpation on his abdomen, flank or spine. There were no neurological deficits. HIV test was negative. The patient's CT of the abdomen and pelvis revealed a pathologic compression fracture at the T12 level (Figure 3). The skin biopsy of the facial lesion showed pseudoepitheliomatous hyperplasia with an inflammatory infiltrate and the presence of broad-based budding fungal organism suggestive of Blastomyces dermatitidis (Figure 4). The fine needle aspiration and bone biopsy as well as the fungal culture confirmed the diagnosis. Subsequent chest imaging showed diffuse nodular opacities in all lung lobes. The final diagnosis was disseminated blastomycosis with bone involvement. The patient was initially started on itraconazole, but due to symptoms of spinal cord compression, was ultimately given amphotericin B. The patient completely improved with this treatment and showed resolution of skin lesions.

Blastomyces dermatitidis is endemic to the Mississippi and Ohio river basins, encompassing many Eastern and Southern states in United States. ${ }^{1-4} \mathrm{It}$ has an annual incidence of 12 - 40 cases per 100000

\footnotetext{
Received on 04.07.2011.

Approved by the Advisory Board and accepted for publication on 22.04.2012.

* Study carried out at Virginia Comonwealth University (VCU) - Richmond, Virginia, United States.

Conflict of interest: None

Financial funding: None

MD - Medical Resident - Virginia Comonwealth University (VCU) - Richmond, Virginia, United States.

(C)2013 by Anais Brasileiros de Dermatologia
} 


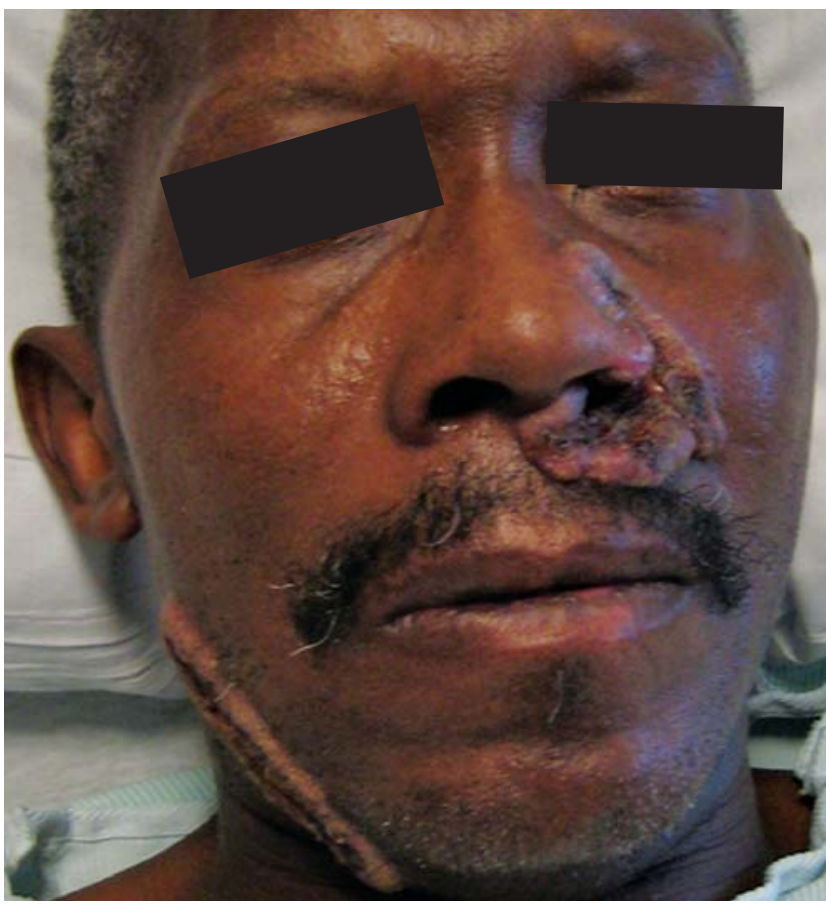

FIGURE 1: Patient with a couple of verrucous and eroded plaques on the face
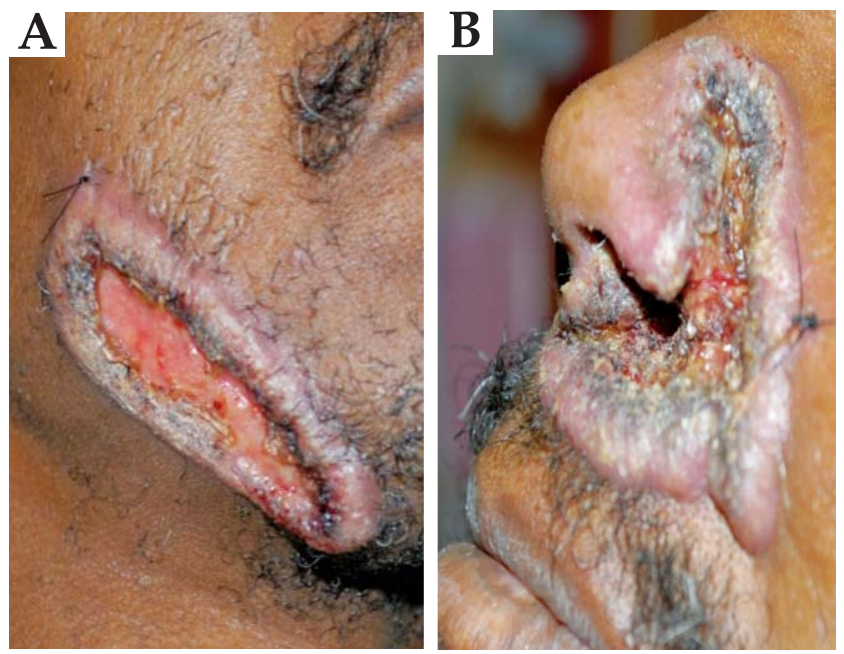

Figure 2: A close up of the lesions on the face

within endemic regions. ${ }^{1}$ It also affects patients in Africa and Canada. ${ }^{1,3,4}$ Blastomyces dermatidis affects primarily the lungs, skin, and other viscera. The most important form is primary pulmonary blastomycosis. Most cases are asymptomatic; the rest displays mild to severe respiratory findings similar to tuberculosis or other systemic mycosis. ${ }^{3}$ Skin involvement has been reported in $40-80 \%$ of the cases. The cutaneous manifestations of blastomycosis come in two forms, verrucous and ulcerative. ${ }^{1,2}$ Five categories of blastomycosis

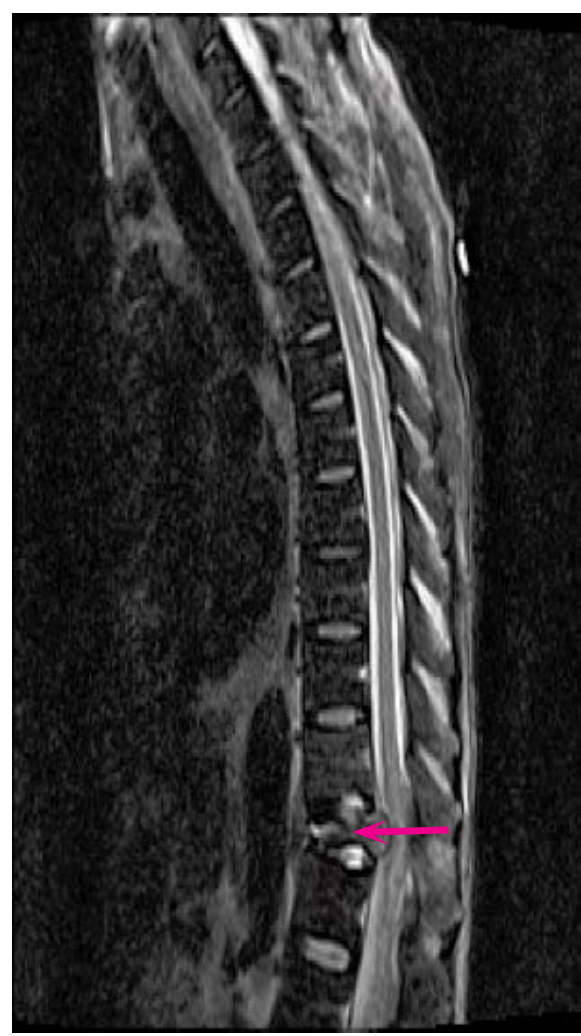

FIGURE 3: The arrow indicates the compression fracture at the T12 level
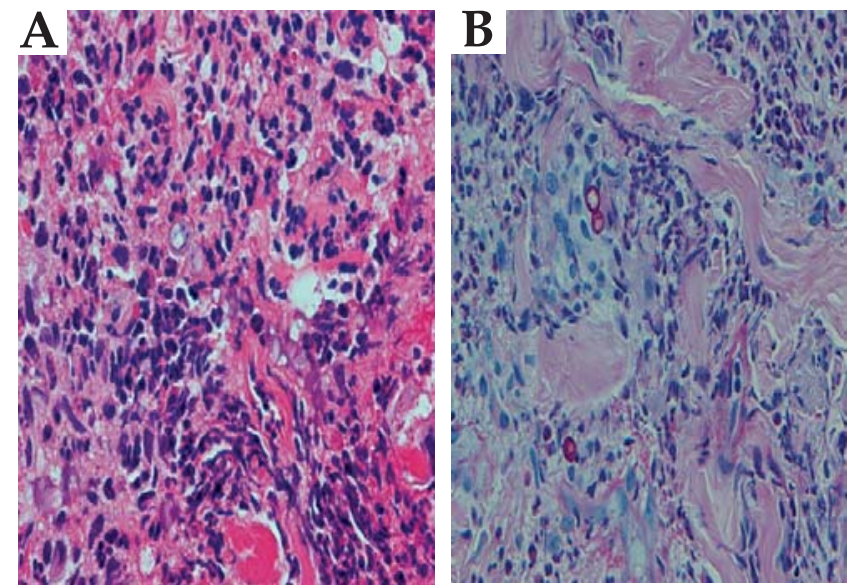

FIGURE 4: H\&E and PAS staining of the skin biopsy showing mixed inflammatory infiltrate and fungal organisms. (Courtesy Dr Nooshin K Brinster, MD,Virginia Commonwealth University)

have been defined: primary pulmonary disease, single organ system disease, generalized multiorgan disease, chronic cutaneous disease and inoculation blastomycosis.

The greatest challenge in making the diagnosis of blastomycosis is difficult recognition of the condition. ${ }^{1}$ Without treatment, the prognosis is grave when infection spreads beyond the lung; the case fatality rate for disseminated blastomycosis was $78 \%$ prior to the availability of specific fungal therapy. ${ }^{1}$ The dis- 
seminated form of blastomycosis is not typically diagnosed until late in its course, consequently affecting morbidity. ${ }^{2}$ Early diagnosis and therapy can lead to resolution and prevent clinical relapse. No clinical or radiographic abnormalities are absolutely diagnostic of blastomycosis, therefore visualization of the characteristic yeast forms or growth of the fungus in culture is necessary for diagnosis. ${ }^{1}$ Cutaneous alternariosis can also mimick blastomycosis, which must be differentiated by culture. ${ }^{5}$

The differential diagnoses of cutaneous blastomycosis include dimorphic fungi, basal cell carcinoma, squamous cell carcinoma, giant keratoacanthoma, scrofuloderma, lupus vulgaris, atypical mycobacteri- um, nocardiosis, syphilis, bromoderma, iododerma, leishmaniasis, granuloma inguinale, lymphoma and pyoderma gangrenosum..$^{1-3}$ This case highlights the clinical manifestations of disseminated blastomycosis and stresses the importance of maintaining a high index of suspicion in an endemic region. Moreover, imported cases have been reported in the literature. ${ }^{5}$ It is critical for the diagnostician to recognize the clinical pattern of lesions that can be restricted to the skin and mucous surfaces or even present as visceral dissemination. Dermatologists from all over the world should be prepared to recognize and diagnose tropical mycoses. ${ }^{6}$

\section{REFERENCES}

1. Saccente M, Woods Gl. Clinical and laboratory update on blastomycosis. Clin Microbiol Rev. 2010;23:367-81.

2. Mason AR, Cortes GY, Cook J, Maize JC, Thiers BH. Cutaneous blastomycosis: a diagnostic challenge. Int J Dermatol. 2008;47:824-30.

3. Bonifaz A, Vázquez-González D, Perusquía-Ortiz AM. Endemic systemic mycoses: coccidioidomycosis, histoplasmosis, paracoccidioidomycosis and blastomycosis. J Detsch Dermatol Ges. 2011; 9:705-14.

4. Rodríguez-Mena A, Mayorga J, Solís-Ledesma G, Barba-Gómez J. Blastomycosis: report of an imported case in Mexico, with only cutaneous lesions. Rev Iberoam Micol. 2010;27:210-2.

5. Osmond GW, Walters RW, Puri PK. Cutaneous alternariosis microscopically mimicking blastomycosis. J Cutan Pathol. 2011;38:923-5.

6. Lupi 0, Tyring SK, McGinnis MR. Tropical dermatology: fungal tropical diseases. J Am Acad Dermatol. 2005;53:931-51.

\author{
MAILING ADDRESS: \\ Alex G Ortega-Loayza \\ Virginia Commonwealth University \\ MCV Campus \\ Department of Dermatology \\ 401 North 11th Street \\ Richmond, VA 23298 \\ E-mail: aortegaloayza2@mcvh-vcu.edu
}

How to cite this article: Ortega-Loayza AG, Nuyen T. Cutaneous blastomycosis: a clue to a systemic disease. An Bras Dermatol. 2013;88(2):287-9. 